\title{
PREZENTACJE
}

Stanislaw Majewski

(Kielce)

\section{Dorobek naukowy historyków oświaty i wychowania środowiska kieleckiego}

\section{Wprowadzenie}

Kielecki ośrodek badań historyczno-oświatowych należy do młodszych w kraju, a jego rozwój nastąpił w ostatnim trzydziestoleciu i wiąże się z powstaniem pierwszej humanistycznej uczelni Wyższej Szkoły Pedagogicznej. Odtąd badania naukowe nabrały w pełni charakteru instytucjonalnego. Uczelnia ta pełniła ponadto funkcję koordynatora badań, współpracując np. z Kieleckim Towarzystwem Naukowym i wspierając wysiłki pojedynczych badaczy. Drugą charakterystyczną cechą prezentowanego ośrodka to współpraca i mecenat ze strony mających już długą tradycję ośrodków akademickich kraju, głównie Krakowa, Warszawy, Łodzi, Lublina i innych. W uczelniach mających pełne prawa akademickie kieleccy historycy oświaty zdobywali stopnie doktorskie i pomyślnie realizowali przewody habilitacyjne. Na początku XXI w. kielecki ośrodek dysponuje już dużym potencjałem naukowym reprezentowanym przez kilkudziesięciu profesorów i doktorów.

W dynamice rozwojowej ważną rolę odegrał fakt uzyskania przez Instytut Historii Akademii Świętokrzyskiej prawa do doktoryzowania i habilitacji. Obok tej jednostki badania historyczno-oświatowe prowadzone są w zakładzie Historii Wychowania i Organizacji Szkolnictwa Instytutu Pedagogiki i Psychologii. Dorobek naukowy kieleckiego ośrodka można podzielić na kilka grup:

- monografie ogólnopolskie i regionalne z dziejów szkolnictwa, w tym także monografie najbardziej zasłużonych szkół i innych placówek naukowych w regionie,

- wydawnictwa źródłowe i metodologia badań historyczno-oświatowych,

- artykuły i rozprawy dotyczące zarówno dziejów oświaty, jak i myśli pedagogicznej,

- recenzje wydawnictw naukowych,

- podręczniki akademickie do historii wychowania.

Kieleccy historycy publikowali swoje prace w renomowanych wydawnictwach ogólnopolskich, regionalnych, a także w wydawnictwie uczelnianym, które jako priorytetowe wydaje prace doktorskie i habilitacyjne. Wiele prac stanowi część składową zwartych opracowań uniwersyteckich i Polskiej Akademii Nauk. 
Nie brakuje też prac kieleckich autorów na łamach czołowych specjalistycznych periodyków, jak np. „Przegląd Historyczno-Oświatowy” czy „Rozprawy z Dziejów Oświaty". Na Akademii Świętokrzyskiej zarówno w Instytucie Historii, jak i Pedagogiki i Psychologii ukształtowały się i umocniły seryjne wydawnictwa, jak np. „Między Wisłą a Pilicą" czy „Kieleckie Studia Pedagogiczne”, a obecnie „Studia Pedagogiczne Akademii Świętokrzyskiej".

Wyrazem aktywności kieleckiego środowiska naukowego jest organizacja specjalistycznych konferencji historyczno-oświatowych, których plonem są monumentalne wydawnictwa jak np. Historia wychowania w XX wieku. Dorobek i perspektywy pod red. T. Gumuły, J. Krasuskiego, S. Majewskiego (Kielce 1998) oraz Historia wychowania w kształceniu nauczycieli. Tradycja $i$ współczesność pod red. T. Gumuły i S. Majewskiego (Kielce 2003). Obecnie, zgromadzenie uczonych czołowych ośrodków akademickich kraju - Pierwsze Biennale Historyków Edukacji - „Być dzieckiem w XVIII-XX wieku”, obradujące w sercu prastarych Gór Świętokrzyskich, zorganizowane przez Towarzystwo Historii Edukacji, Zakład Historii Wychowania i Organizacji Szkolnictwa i Instytut Historii Nauki PAN, jest też optymistycznym dowodem współpracy historyków wychowania $\mathrm{z}$ przedstawicielami innych dyscyplin naukowych. Podobne tendencje można zaobserwować w kieleckim środowisku naukowym.

Niniejsze opracowanie nie jest pierwszą próbą podsumowania dorobku kieleckiego środowiska historyków oświaty. Refleksję nad dorobkiem historyków regionu świętokrzyskiego w dziedzinie dziejów oświaty i wychowania podjął S. Możdżeń, który dokonał próby syntetycznej oceny tego dorobku i sporządził Bibliografię historii oświaty na Kielecczyźnie do 1984 roku'. W 1978 r. S. Majewski omówił dorobek naukowy zakładu Historii Wychowania i Organizacji Szkolnictwa Wyższej Szkoły Pedagogicznej², a B. Szabat i M. Wrzosek dorobek Instytutu Historii WSP w Kielcach w zakresie badań nad dziejami oświaty i wychowania ${ }^{3}$. Od tego czasu liczba publikacji zwartych oraz artykułów i rozpraw kieleckich historyków oświaty i wychowania znacznie się zwiększyła i zamyka się liczbą kilkuset pozycji bibliograficznych.

\section{Okres staropolski}

Dorobek historyków oświaty tego okresu jest cenny ze względu na rozległą podstawę źródłową opublikowanych prac. Już w 1964 r. ukazał się w Krakowie pierwszy tom Dziejów Uniwersytetu Jagiellońskiego w latach 1364-1764 pod red. K. Lepszego, w którym współautorami są Z. Trawicka i W. Urban. Na szczególną uwagę zasługuje monumental-

${ }^{1}$ S. Możdżeń, Naukowy dorobek Kielecczyzny w zakresie historii oświaty $i$ wychowania, idem, Bibliografia historii oświaty na Kielecczyźnie do 1984 r., w: Glówne problemy oświaty $i$ wychowania na Kielecczyźnie w 40-leciu PRL, red. J. Krasuski, Z. Ruta, Kielce 1987.

${ }^{2}$ S. Majewski, Dorobek naukowy Zaktadu Historii Wychowania i Organizacji Szkolnictwa Wyższej Szkoty Pedagogicznej im. Jana Kochanowskiego w Kielcach do 1997 r., w: Historia wychowania w XX wieku. Dorobek $i$ perspektywy, red. T. Gumula, J. Krasuski, S. Majewski, Kielce 1998, s.592-601.

${ }^{3}$ B. Szabat, M. Wrzosek, Dorobek Instytutu Historii WSP w Kielcach $w$ zakresie badań nad dziejami oświaty $i$ wychowania, w: Historia wychowania w XX wieku, s. 582-592. 
ne dzieło ks. M. Rusieckiego opublikowane w 1996 r. przez Katolicki Uniwersytet Lubelski Przedmiot Katechezy potrydenckiej w Polsce (1566-1699) z imponującą bazą źródłową. Kolejną pracą obejmującą częściowo okres staropolski jest rozprawa A. Massalskiego Szkolnictwo średnie Kielc do 1862 r. podobnie jak poprzednie - dobrze udokumentowana źródłowo.

\section{Okres zaborów 1795-1918}

Lata niewoli narodowej i braku państwowości są przedmiotem rozległej i szczegółowej analizy kieleckich historyków oświaty zarówno z Instytutu Historii, jak i Instytutu Pedagogiki i Psychologii. Badania te zapoczątkowane zostały już na początku lat 80 . W 1983 r. ukazała się praca W. Cabana Szkolnictwo elementarne na ziemi kielecko-radomskiej (1809-1862). Dalej należy wymienić rozprawę Z. Małeckiego, Nauczyciele rzqdowych szkól elementarnych na poludniu i w poludniowo-wschodniej część Królestwa Polskiego w okresie międzypowstaniowym 1832-1962 oraz prace B. Szabat, Szkolnictwo poczqtkowe Kielc i powiatu kieleckiego w latach 1864-1915 i Walka o szkole polskq w okresie rewolucji 1905-1907 w guberni kieleckiej. Zarówno praca Z. Małeckiego, jak i rozprawy B. Szabat, które ukazały się na początku lat 90 . wskazywały, że w kieleckim środowisku historyków oświaty wiek XIX staje się najbardziej penetrowanym okresem badań. Potwierdzają to prace S. Możdżenia dotyczące szkolnictwa galicyjskiego. Były to: Ustrój szkoty średniej w Galicji i próby jego modernizacji w latach 1948-1984 oraz Reformy szkoły średniej w Galicji w latach 1984-1914. Pierwsza praca ukazała się w 1974 r., druga przedstawiona przez Autora jako praca habilitacyjna w 1979 r.

Lata 90. przyniosły w środowisku kieleckim poszerzenie badań nad oświatą w zaborze rosyjskim XIX w. i Galicji doby autonomii. Ukazało się wówczas kilka cennych monografii zgromadzonych $w$ archiwach polskich i rosyjskich.

Największe zasługi jako organizator, koordynator badań, a następnie promotor prac doktorskich, który potrafił skupić wokół siebie zespół badawczy, ma niewątpliwie prof. Adam Massalski. W roku 2001 opublikował on monografię zatytułowaną Szkoły średnie rzqdowe męskie na ziemi kielecko-radomskiej w latach 1833-1862, a wkrótce potem kolejną książkę Zwierzchnicy rzq̨dowych męskich szkól średnich w Królestwie Polskim w latach 1833-1862 (Kielce 2004).

$\mathrm{Na}$ seminarium doktorskim prowadzonym przez A. Massalskiego opracowanych zostało i obronionych pomyślnie kilka prac, które zostały skierowane do druku. Jedną z najcenniejszych, która została opublikowana jest rozprawa E. Kuli Naukowa, literacka i artystyczna twórczość nauczycieli męskich rzqdowych szkót średnich Królestwa Polskiego w latach 1833-1862 (Kielce 2006). Wcześniej, w 2003 r. M. Czapska opracowała i wydała pracę pt. Prywatne szkoły średnie w Królestwie Polskim 1831-1862.

Jak wynika z powyższej analizy przedmiotem szczególnego zainteresowania historyków oświaty Akademii Świętokrzyskiej stał się okres międzypowstaniowy w Królestwie Polskim. Schyłkowe lata okresu zaborów stały się przedmiotem zainteresowań B. Szabat, która po latach intensywnych badań wydała książkę Walka o szkołę polskg w okresie rewolucji 1905-1907 w guberni kieleckiej" (Kielce 2001). Gdy chodzi o oświatę w Galicji 
najcenniejszym opracowaniem ostatnich lat jest książka M. Pękowskiej Lwowskie zakłady dla gluchych i niewidomych dzieci w latach 1830-1914 (Kielce 2004). Można ją uznać za monografię, gdyż autorka przedstawiła pełne dzieje tych placówek (organizację, finansowanie, problematykę edukacyjno-wychowawczą, formację intelektualno-dydaktyczną kadry pedagogicznej, oddziaływanie społeczne tych zakładów w środowisku, a to $\mathrm{z}$ kolei podnosiło świadomość społeczeństwa o potrzebie zapewnienia dzieciom specjalnej troski jak najlepszej opieki).

\section{Okres międzywojenny}

$\mathrm{Na}$ szczególną uwagę zasługuje dorobek naukowy J. Grzywny, który przez wiele lat pracował zarówno Instytucie Historii, jak i Pedagogiki i Psychologii kieleckiej WSP. $Z$ jego dorobku naukowego należy przede wszystkim wymienić prace zwarte na temat dziejów szkolnictwa i oświaty w województwie kieleckim w latach 1918-1939. Szczególną rolę w jego dorobku odgrywa niewątpliwie praca Szkolnictwo powszechne $i$ oświata pozaszkolna $w$ województwie kieleckim 1918-1939, która stała się podstawą do uzyskania stopnia naukowego doktora habilitowanego. Bogato udokumentowane źródłowo są także pozostałe prace tego autora: Zwiqzek Nauczycielstwa Polskiego na Kielecczyźnie w latach 1905-1939 (Kielce 1977), Klerykalizacja szkolnictwa na Kielecczyźnie w opinii publicznej 1919-1939 (Kielce 1973) - Robotniczy ruch oświatowo-kulturalny na Kielecczyźnie do 1918 roku (Kielce 1989), Polski i żydowski ruch oświatowo-kulturalny $w$ środowisku robotniczym województwa kieleckiego 1918-1939 (Kielce 1991). W dorobku naukowym J. Grzywny niewątpliwie ważne miejsce zajmuje książka Zwiazek Nauczycielstwa Polskiego na Kielecczyźnie latach 1905-1939 (Kielce 1993), oparta na różnorodnych źródłach archiwalnych i prasie nauczycielskiej. Jest to jedyne zwarte opracowanie na temat zawodowego ruchu nauczycielskiego na Kielecczyźnie. Wielce do lepszego poznania szkolnictwa województwa kieleckiego przyczynił się Z. Ruta, który przez wiele lat organizował badania historyczno-oświatowe w środowisku kieleckim, ale sam opracował i wydał pracę Szkolnictwo powszechne w okręgu szkolnym krakowskim 1918-1939, w której uwzględnił oprócz województwa krakowskiego województwo kieleckie, należące od 1927 r. do okręgu szkolnego krakowskiego.

Jednym z ostatnich cennych wydawnictw dotyczących okresu II Rzeczypospolitej jest praca D. Krześniak-Firlej, Księża prefekci diecezji kieleckiej 1919-1939 (Kielce 2001). Jest ona niewątpliwym fenomenem na rynku wydawniczym ostatnich lat. Księża prefekci stanowili wśród nauczycielstwa szkół powszechnych średnich ważną grupę zawodową. Na mocy Konstytucji Rzeczypospolitej i Konkordatu ze Stolicą Apostolską, ustaw oświatowych z 1932 r. wychowanie religijne było nieodłącznym elementem procesu wychowawczego szkoły polskiej. Stąd też staranny dobór nauczycieli religii. Ich aktywność wykraczała daleko poza proces nauczania religii, byli niejednokrotnie animatorami życia kulturalno-oświatowego w środowisku. Dociekania D. Krześniak-Firlej prowadzą także do wniosku, że księża prefekci byli aktywni na polu naukowym i publicystycznym. Praca została wzorowo przygotowana do druku, jest bogato udokumentowana źródłowo. Autorka wykorzystała źródła zarówno placówek archiwalnych kościelnych, jak i państwowych. 
Podsumowując okres zaborów i II Rzeczypospolitej warto przypomnieć, że osiągnięcia badawcze wymienionych wyżej autorów są też wynikiem sprawnej organizacji tych badań przez takich historyków, jak wspomniany już prof. A. Massalski, ks. prof. D. Olszewski, prof. M. Markowski i inni.

\section{Okres II wojny światowej}

Na początku lat 70. kieleckie środowisko naukowe Wyższej Szkoły Pedagogicznej zasilił dr J. Krasuski, wykładowca Studium Nauczycielskiego w Radomiu i na krótko Instytutu Historii PAN w Warszawie. Był po obronie pracy doktorskiej u prof. Ł. Kurdybachy, która już była przygotowana do druku w Państwowym Wydawnictwie Naukowym. Praca ta ukazała się w 1971 r. pt. Tajne szkolnictwo polskie w okresie okupacji hitlerowskiej 1939-1945, a w 1977 r. ukazało się jej drugie wydanie. Książka wzbudziła duże zainteresowanie nie tylko wśród historyków wychowania, lecz także uczestników tajnego nauczania, doczekała się też kilkunastu recenzji naukowych. W pracy J. Krasuskiego znalazły się liczne odniesienia dotyczące województwa kieleckiego. Najcenniejszą pracą dotyczącą okupacyjnych dziejów szkolnictwa na Kielecczyźnie jest jednak źródłowa praca A. Massalskiego Szkolnictwo na Kielecczyźnie w okresie okupacji 1939-1945 (Kraków 1975). Autor zebrał w niej rozległy zespół źródeł zarówno archiwalnych, jak też wywołanych. Nawiązał kontakt $\mathrm{z}$ organizatorami tajnego nauczania, m.in. J. Kupcem, przewodniczącym Tajnej Organizacji Nauczycielskiej okręgu kieleckiego. Ustaleń A. Massalskiego dotyczących organizacji i zasięgu tajnego szkolnictwa nie podważył do tej pory żaden historyk wychowania.

\section{Po II wojnie światowej}

Do lat 70. XX w. publikacje na temat szkolnictwa województwa kieleckiego ograniczały się zaledwie do kilku artykułów. Pierwszym poważniejszym opracowaniem jest praca Upowszechnianie oświaty $i$ kultury w powiecie kieleckim w latach 1945-1975 pióra J. Grzywny (Kielce 1974). Zakrojone na szerszą skalę badania nad szkolnictwem ogólnokształcącym zarówno podstawowym, jak i średnim w połowie lat 70. rozpoczął $\mathbf{S}$. Majewski, uwieńczone doktoratem w 1983 r. na podstawie dysertacji „Organizacja szkolnictwa ogólnokształcącego województwie kieleckim 1944-1961", której promotorem był prof. Z. Ruta. Poszerzając badania, wspomniany autor opublikował dwie prace: Organizacja szkolnictwa podstawowego w województwie kieleckim 1944-1961 (Kielce 1993) i Organizacja szkolnictwa średniego ogólnokształcqcego $w$ województwie kieleckim 1944-1961" (Kielce 1975). Prace oparte zostały na źródłach archiwów centralnych i regionalnych. Pokazują odbudowę szkolnictwa na Kielecczyźnie, sieć szkolną, rozwój bazy lokalowo-materialnej szkół, kadry, efekty pracy szkół itp. Kontynuacją podjętych badań stał się okres 1961-1975. S. Majewski opublikował kolejną książkę Przemiany szkolnictwa ogólnoksztalcqcego $w$ województwie kieleckim 1961-1975 (Kielce 2000), 
w której przedstawił realizację reformy szkolnictwa na podstawie ustawy z 15 lipca $1961 \mathrm{r}$. na terenie okręgu szkolnego kieleckiego.

$\mathrm{Na}$ naukowe opracowanie czeka nadal szkolnictwo średnie zawodowe oraz szkolnictwo wyższe na Kielecczyźnie.

\section{Podręczniki do historii wychowania i wydawnictwa źródłowe}

Z kieleckiego środowiska historyków oświaty wyszło kilka edycji podręczników i źródeł. Początek dał J. Krasuski, który wydał dwie wersje jednotomowego podręcznika do historii wychowania ${ }^{4}$. Wieloletni trud opracowywania podręczników podjął S. Możdżeń już na początku lat 90 . Podręczniki opracowywane przez tego autora charakteryzują się tradycyjną periodyzacją. Poszczególne części dotyczą lat: od starożytności do 1795 r., 1795-1918, 1918-1945. Uzupełnieniem podręczników jest osiem części źródeł do historii wychowania charakteryzujących poszczególne okresy historyczne (starożytność, średniowiecze, odrodzenie, wiek XVII, oświecenie, wiek XIX i początek XX w., szkolnictwo w Polsce 1919-1945). Podręczniki S. Możdżenia są bogate faktograficznie, zaś w tekstach źródłowych widać poszukiwanie nowych, nieznanych do tej pory dokumentów. Prace S. Możdżenia cieszą się dużym zainteresowaniem studentów zarówno studiów magisterskich, jak i licencjackich ${ }^{5}$.

\section{Metodologia badań historyczno-oświatowych}

W tej stosunkowo młodej dyscyplinie naukowej wykorzystującej nie tylko metody badań pedagogicznych, lecz także historycznych, ośrodek kielecki ma poważne osiągnięcia. Pierwszą próbą opracowania tego zagadnienia był przewodnik metodyczny do prac magisterskich trzech autorów, znanych historyków J. Grzywny, Z. Guldona i S. Możdżenia, Podstawy warsztatu historyka oświaty. Praca składa się z kilku podrozdziałów, uwzględnia takie problemy, jak: bibliografia, wydawnictwa ogólne i czasopisma pedagogiczne, prasa XVII-XX w., archiwa, zbiory rękopiśmiennicze bibliotek, źródła wywołane, zasady wykorzystywania i porządkowania notatek, charakter, konstrukcja i kryteria oceny prac magisterskich, technika pisania prac magisterskich. Książka spotkała się z żywym zainteresowaniem i studentów historii, i pedagogiki, piszących prace magisterskie $\mathrm{z}$ historii wychowania i niewątpliwie przyczyniła się do zbliżenia poglądów obu środowisk naukowych na temat wymogów stawianych pracom magisterskim. Wkrótce ukazało się drugie wydanie tej pracy ${ }^{6}$. Dociekania naukowe na temat metodologii historii wychowania jako dyscypliny naukowej znacznie rozszerzył i uporządkował S. Możdżeń wydając dzieło Praca naukowa historyka oświaty (Sandomierz 2001). Jest

\footnotetext{
${ }^{4}$ Por.: J. Krasuski, Historia wychowania. Zarys syntetyczny, Warszawa 1989.

${ }^{5}$ S. Możdżeń, Historia wychowania do 1795 r., Kielce 2005. idem, Historia wychowania 1795-1918, Kielce 2000; idem, Historia wychowania 1918-1945, Kielce 2000.

${ }^{6}$ J. Grzywna, Z. Guldon, S. Możdżen, Podstawy warsztatu historyka oświaty. Przewodnik metodyczny do prac magisterskich, Kielce 1994.
} 
ono adresowane juź nie tylko do studentów piszących prace magisterskie, ale też do wytrawnych historyków i pedagogów mających w kręgu zainteresowań badawczych historię oświaty. Autor traktuje historię wychowania jako część historii, zwłaszcza historię kultury, podaje bogaty zestaw pozycji bibliograficznych, omawia etapy postępowania badawczego historyka oświaty, konstrukcję prac naukowych i elementy ich oceny; jest to praca aspirująca do syntezy metodologii badań historii wychowania.

\section{Studia interdyscyplinarne \\ - historia wychowania a pedagogika porównawcza}

Specyfiką badań historyczno-pedagogicznych w środowisku kieleckim jest łączenie historii wychowania $\mathrm{z}$ innymi subdyscyplinami pedagogicznymi - głównie pedagogiką porównawczą. Pierwszą publikacją łączącą dwie dyscypliny stała się praca Organizacja i funkcjonowanie wspólczesnych systemów edukacyjnych. Jest to antologia dokumentów i materiałów przygotowanych przez T. Gumuję, J. Krasuskiego S. Majewskiego, składająca się z trzech części:

- współpraca międzynarodowa w dziedzinie oświaty i wychowania,

- organizacja systemu edukacyjnego Polsce,

- wybrane problemy organizacji systemów edukacyjnych na świecie.

Publikacja została przygotowana z myślą o studentach pedagogiki, a zgromadzone w niej najważniejsze dokumenty i materiały mają ukazać rolę badań komparatystycznych w rozwoju pedagogiki. W części pierwszej - autorzy zamieścili międzynarodowe deklaracje, konwencje i pakty praw człowieka, fragmenty międzynarodowych raportów o stanie oświaty, dokumenty dotyczące osiągnięć UNESCO itp. W części drugiej - znalazły się dokumenty pokazujące przemiany polskiego systemu od 1932 r., tj. ustawy reformujące szkolnictwo z lat 1932, 1961, 1991, fragmenty ustaw dotyczących statusu prawnozawodowego nauczyciela, niepublikowane dotychczas dokumenty dotyczące polityki oświatowej okupantów w okresie II wojny światowej i wiele innych. Wybrane problemy systemów edukacyjnych $\mathrm{w}$ świecie są przedmiotem trzeciej części prezentowanego wydawnictwa. Pokazane zostały globalne uwarunkowania przemian oświatowych. Autorzy wykorzystali bogate źródła statystyczne, m.in. statystyki szkolnictwa UNESCO, pokazując problemy demograficzne współczesności, tj. nierównomierny przyrost ludności rzutujący na tempo rozwoju szkolnictwa, wydatki na oświatę, poziom scholaryzacji w różnych regionach świata, analfabetyzm, struktury systemów szkolnictwa w różnych krajach. Drugim obszarem zainteresowań pracowników Zakładu Historii Wychowania stał się proces boloński w szkolnictwie wyższym. W pracy zatytułowanej Europejski obszar szkolnictwa wyższego E. Kula i M. Pękowska zgromadziły dokumenty i materiały dotyczące procesu bolońskiego. W części pierwszej - omówiony został rozwój procesu bolońskiego. W części drugiej - znajdują się fragmenty raportów edukacyjnych, traktatów, konwencji, deklaracji i postanowień, których centrum zainteresowania jest szkolnictwo wyższe.

Oprócz dokumentów europejskich zamieszczono też dokumenty unijne, gdyż one odgrywały inspirującą rolę w tworzeniu wspólnego obszaru szkolnictwa wyższego. Dokumenty zostały przedstawione $w$ układzie chronologicznym. Po nich zamieszczono wybrane komunikaty Komisji Europejskiej. Trzecia część prezentuje udział Polski w pro- 
cesie bolońskim oraz strategie rozwoju szkolnictwa wyższego w Polsce. Dodajmy, że autorki w swych badaniach poszły dalej, prezentując kolejną zbiorową pracę, pokazującą realizację procesu bolońskiego w europejskim szkolnictwie wyższym ${ }^{7}$.

\section{Organizacja konferencji historyczno-oświatowych}

Kieleckie środowisko historyków oświaty ma duże tradycje w zakresie organizowania konferencji naukowych poświęconych przemianom oświatowym w Polsce i problemom metodologicznym historii wychowania. Spośród najbardziej reprezentatywnych spotkań tego rodzaju wymienić należy sesję naukową „Szkolnictwo i oświata na Kielecczyźnie w 40-leciu PRL" zorganizowaną przez ówczesny Instytut Pedagogiki, Kuratorium Oświaty i Wychowania, Komendę Chorągwi ZHP, Wojewódzką Bibliotekę Pedagogiczną oraz Zespół Szkół Elektrycznych w Kielcach. W obradach wzięło udział kilkadziesiąt osób: polityków oświatowych, dyrektorów szkół, historyków oświaty i wychowania. W książce po sesji opublikowano 18 artykułów, które zostały zgrupowane w dwie tematycznie spójne części. Pierwsza, zawierająca pięć artykułów dotyczy problematyki oświaty i wychowania w Polsce Ludowej. Druga ma charakter regionalny i obejmuje zagadnienia oświaty na Kielecczyźnie w pierwszym czterdziestoleciu PRL. Jednym z najcenniejszych opracowań w omawianej książce jest bibliografia historii oświaty i wychowania na Kielecczyźnie do 1984 r. Dodać wypada, że omawiana sesja jest do tej pory jedynym zgromadzeniem uczonych, którzy podjęli próbę oceny dorobku województwa kieleckiego w dziedzinie szkolnictwa po II wojnie światowej.

Zbiorowym wysiłkiem Zakładu Historii Wychowania i Organizacji Szkolnictwa w dniach 19-20 maja 1997 r. została zorganizowana w Wólce Milanowskiej międzynarodowa konferencja poświęcona ocenie dorobku i perspektyw historii wychowania w XX w. Licząca ponad 600 stron publikacja wydana w $1998 \mathrm{r}$. zawiera 70 artykułów wybitnych przedstawicieli historii wychowania wszystkich znaczących ośrodków badawczych kraju oraz Słowacji i Białorusi. W ksiąźce znalazły się m.in. rozprawy autorstwa B. Suchodolskiego, S. Wołoszyna - jedne z ostatnich w ich dorobku naukowym. Ukazano w niej kierunki badań historyczno-oświatowych, twórców polskiej historii wychowania i dorobek naukowy poszczególnych ośrodków naukowych kraju. Kilka lat potem, wyżej wymieniony zakład wspólnie z Międzywydziałowym Studium Pedagogicznym zorganizował kolejną konferencję naukową „Historia wychowania w kształceniu nauczycieli”, a jej plonem stała się książka pod tym samym tytułem (2005). Składa się ona z czterech części:

- historia wychowania jako nauka i dyscyplina akademicka,

- stanowiska metodologiczne w badaniach historyczno-oświatowych,

- znaczenie historii wychowania w przygotowaniu kandydatów na nauczycieli,

- edukacja historyczna w kształtowaniu postaw patriotyczno-obywatelskich.

Opublikowane w książce 44 rozprawy znacznie wzbogacają dotychczasowy dorobek historii wychowania w Polsce.

\footnotetext{
${ }^{7}$ Szkolnictwo wyższe $w$ Europie $i$ w Polsce $w$ świetle zatożeń $i$ realizacji procesu bolońskiego, red. E. Kula, M. Pękowska, Kielce 2004.
} 


\section{Podsumowanie}

Przedstawiony w wielkim skrócie dorobek kieleckich historyków oświaty pozwala wyciągnąc kilka wniosków. W ciągu około 35 lat ukształtował się profil badawczy tego ośrodka, obejmujący głównie dwa ostatnie wieki (XIX-XX). Ukazało się drukiem kilkadziesiąt prac zwartych opartych na źródłach archiwalnych. Kieleccy historycy oświaty dokonują kwerend w archiwach na Wschodzie (Rosja, Ukraina, Białoruś), w centralnych archiwach w Polsce (Archiwum Główne Akt Dawnych i Archiwum Akt Nowych) w placówkach regionalnych oraz największych bibliotekach kraju. Opublikowane książki zyskały pozytywne recenzje i dobrze wpisały się w ogólnopolski dorobek historii wychowania, zaś badacze dziejów szkolnictwa i oświaty znaleźli miejsce wśród wybitnych polskich historyków oświaty.

Brak miejsca $w$ niniejszym opracowaniu uniemożliwia autorowi przedstawienie licznych artykułów, rozpraw autorów kieleckich, licznych prac zbiorowych wydawanych przez polskie uniwersytety i inne szkoły wyższe z Krakowa, Rzeszowa, Lublina (KUL i UMCS), Warszawy, Gdańska, Olsztyna, Białegostoku, Wrocławia i innych. Publikowali tam swe prace: A. Massalski, T. Gumuła, W. Firlej, D. Krzesniak - Firlej, M. Czapka, J. Krasuski, S. Możdżeń, E. Kula, M. Stawiak- Ososińska, M. Pękowska, S. Majewski i inni .

Wyrazem konsolidacji i współpracy dwóch instytutów Akademii Świętokrzyskiej Instytutu Historii oraz Instytutu Pedagogiki i Psychologii jest wydanie dwóch monotematycznych roczników „Studiów Pedagogicznych” AŚ (nr 14 i 15), poświęconych wyłącznie historii wychowania, pod redakcją ks. M. Rusieckiego, S. Majewskiego, W. Firleja. Znajdują się tam prace: A. Massalskiego, A. Meissnera, K. Duraj-Nowakowej, J. Krasuskiego, S. Majewskiego, W. Firleja, E. Kuli, M. Pękowskiej, ks. M. Rusieckiego, D. Krzesniak-Firlej, M. Stawiak-Ososińskiej, T. Gumuły, J. Jadacha, M. Kątnego, A. Feliska $\mathrm{i}$ innych.

$\mathrm{Z}$ uznaniem czołowych polskich historyków oświaty spotykają się zawsze kieleckie inicjatywy organizacji konferencji naukowych, których dorobek - jak wspomniano na wstępie - ukazuje się w postaci opracowań książkowych.

Jako jeden z postulatów badawczych warto zasygnalizować potrzebę opracowania całości dorobku naukowego kieleckiego środowiska historyków oświaty.

\footnotetext{
${ }^{8}$ Jedynie przykładowo warto wymienić: Oblicze ideologiczne szkoły polskiej w latach 1944-1955, red. Ks. E. Walewander, KUL, Lublin 2002; Funkcja prywatnych szkól średnich w II Rzeczypospolitej 1918-1939, red. E. Kryńska, Białystok 2004; Nauki pedagogiczne w teorii i praktyce edukacyjnej, red. J. Kuźma, J. Morbitzer, Kraków 2003; Dzieje kształtowania się polskich instytucji oświatowych, red. E. A. Mierzwa, Piotrków Trybunalski 2002; O'świata, wychowanie i kultura fizyczna w rzeczywistości spoteczno-politycznej Polski Ludowej (1945-1989), Torún 2004; Bibliografia piśmiennictwa profesorów Seminarium Kieleckiego 1727-2001, oprac. D. Krześniak-Firlej, W. Firlej, A. Kaleta, Kielce 2002; Nauka i oświata a spoleczności lokalne na ziemiach polskich w XIX $i X X$ wieku, red. W. Caban, przy wspł. E. Kuli i C. Jastrzębskiego, Kielce 2003.
} 